\title{
Triple Role of Business Model Co-Creation in Business Networks
}

\author{
Marikka Heikkilä \\ Centre for Collaborative Research, Turku School of Economics \\ University of Turku FI-20014 University of Turku, Finland \\ E-mail: marikka.heikkila@utu.fi
}

Received 22 May 2015; Accepted 1 July 2015;

Publication 4 March 2016

\section{Abstract}

This paper focuses on the topics of learning and coordination within emerging business networks. It discusses the triple role of Business Model co-creation process within business networks: first the process helps the business network to learn and create trust between the partners, second it helps the partners to estimate the feasibility and fairness of the cooperation, and third, it helps the business network to agree on the use of differing coordination mechanisms. This paper contributes to the existing literature on business model co-creation and coordination in networked settings.

Keywords: business network, business model, co-creation, innovation, coordination, fairness, collaboration, learning.

\section{Introduction}

Business modelling is already commonly adopted method within companies when they are innovating and sketching new business ideas (CasadesusMasanell and Ricart, 2011). Similarly hot topic is partnering and networking (IBM, 2012). There is a rich scientific literature on business models (BMs)

Journal of Multi Business Model Innovation and Technology, Vol. 3, 37-66.

doi: 10.13052/jmbmit2245-456X.321

(c) 2016 River Publishers. All rights reserved. 
(Bouwman, 2003; Osterwalder, 2004; Timmers, 1998; Chesbrough, 2010; Chesbrough and Rosenbloom, 2002) and business networks (Håkansson and Ford, 2002; Håkansson and Snehota, 1995; Powell, 2000). BM is often referred to as a boundary-spanning concept explaining how the focal firm embeds in and transacts with its surrounding ecosystem (Doganova and Eyquem-Renault, 2009; Teece, 2010; Zott \& Amit, 2010), but research studying development and management of BMs in business networks is still scarce (Frankenberger et al., 2013a, 2013b; Heikkilä et al., 2014; Palo and Tähtinen, 2013). Kohtamäki (2010) calls for theories emphasising shared relationship management and joint value co-creation.

In this article we continue the discussion with the following research question: What is the role of co-creation process of BMs in coordinating the emerging business networks? We study the question in the context of emerging business networks by looking into the co-creation process of BM (co-BM) within business network. We construct a model that depicts the main roles of co-BM highlighting the intertwined role of business modelling and organisational change management in business networks. Building on empirical case data we show how, in the context of business networks, mutual learning, fairness and agreement over coordination mechanisms are core areas in co-creation of BMs (Andersen and Christensen, 2000; Lusch et al., 2010; Westerlund and Rajala, 2010).

The purpose of this proposal is twofold. First, a comprehensive view on the co-creation of business models in business networks will be given through analysis of collaborative development of BMs in two emerging business networks in longitudinal action research case studies. Second, building on the literature and the empirical results a conceptual model of the business model co-creation is proposed. Therefore, this proposal has both scientific as well as managerial relevance. It fosters the understanding of the role of business models and their co-creation in emerging business networks and contributes to the scientific community by generating new knowledge in the fields of business models and business networks, in particularly by putting forward an idea of business model co-creation process being a mechanism for business network coordination.

The remainder of this paper is structured as follows: First we will look into BM and business network literature. Then we describe our empirical study and present the results. In discussion chapter we propose a conceptual model on co-BM. Finally, we draw some conclusions and outline opportunities for future research. 


\section{Business Models}

Business model (BM) depicts the general logic that creates the business value in relation with the organisation's infrastructure, or assets. Osterwalder (2004, p. 14) characterises BM as "the translation of a company's strategy into a blueprint of the company's logic of earning money." Venkatraman and Henderson (1998, p. 46), in turn, define BM as "a coordinated plan to design strategy along the customer interaction, asset configuration and knowledge leverage vectors."

That is, the purpose of BM is to mediate in an orchestrated way strategy to architectural level. It depicts how the business works, i.e. the general logic that creates the business value in relation with the organisation's architecture/infrastructure. Therefore BM, as a representation of the corporate or network strategy, is the starting point for planning operative business processes (eFactors, 2003). The literature is rather consistent in the list of main components of a BM (Dubosson-Torbay et al., 2002): Service (the value proposition offered on the market); Customers (segments); Infrastructure (management) and Financials (revenue and expenses with necessary financial mechanisms). Some researchers add Technology as one of the major components as well (Bouwman et al., 2008; Heikkilä et al., 2010).

There is a notable difference in how European and American scholars approach the concept of BM (Bouwman et al., 2012). The European school, originating largely in Information Systems Science, has focused more on ontologies and design methodologies of BMs (Bouwman et al., 2008; Osterwalder and Pigneur, 2010). Increasingly the interest has been on providing BM tools; they have been studied especially in the context of mobile business and networked services (Bouwman et al., 2012). Meanwhile, the American school concentrated on classifying (Afuah and Tucci, 2003) and use of BMs in a context of open innovation (Chesbrough, 2006; 2010; Zott and Amit, 2010). Several scholars promote conceptual BM descriptions as tools to help in designing experiments of new business ideas or testing modifications to old ones (Baden-Fuller and Morgan, 2010; Chesbrough, 2010; Teece, 2010). Lately these two streams have grown to closer to each others: The main interest is now on the practices that help to apply the business modelling approach in real life cases and to consider also dynamics of business modelling (El Sawy and Pereira, 2013) as well as business modelling in business network (Busquets, 2010; Heikkilä et al., 2008; Palo and Tähtinen, 2013).

The studies on BMs in networks have emphasised the dynamic, iterative nature of the process of BM development, especially in networked contexts 
(Grandori, 1997; Heikkilä and Kuivaniemi, 2012; Palo and Tähtinen, 2013; Powell, 2000). There are also studies (Lusch et al., 2010) pointing out the challenges coming from boundary-spanning nature of co-creation of BMs, because rarely one party has the authority over the other parties in the network. It is the whole network with its stakeholders that affect the feasibility of the business model.

\section{Business Networks}

In literature the terms business network, strategic network and value network usually refer to intentionally formed networks where an actor can, at least to a reasonable extent, exert influence and control on the behaviour of other parties of a business network (Christopher, 1998; Möller and Svahn, 2009;

Svahn, 2004; Vervest et al., 2005). The value activities carried out by differing economic players are linked to each other through different flows such as material, information, financial resources and relationships (Parolini, 1999). The contents of these links between actors are the result of investments by both of the counterparts for instance to specific process or knowledge (asset specificity in transaction costs economics, Williamson, 1985) during the collaboration.

The stronger the relations between the partners the more impact they have on the business but also on setting restrictions to the freedom of the actors (Ford and Håkansson, 2006). This means that the actors have to make decisions over which relations they are willing to invest in and commit to. This view is also reflected for instance in Rosenfeld (1995) identifying the intentionality and restricted nature of the business network; The aim of business network is to provide mutual (financial) gain by engaging in cooperation and establishing relationships that make partners' businesses dependent on each other.

Next we will analyse three aspects of business networks, which the above definitions and related literature point out: feasibility and fairness, learning and coordination in business networks.

\subsection{Feasibility and Fairness in Business Networks}

Ultimately, the motivation for organisations to join a network is the attainment of goals that are unachievable by the organisations independently (Van de Ven, 1976). The firms may enter alliances in order to gain fast access to new markets or new technologies, or they may try to shape competition, or gain legitimacy (Baraldi et al., 2011; Nielsen, 2002; Powell, 1990; 
Tsai \& Ghoshal, 1998). Business networks are considered especially useful for the exchange of qualities or commodities whose value is difficult to evaluate, like know-how, technological capability, a particular method or style of production, or a spirit of innovation and experimentation (Powell, 1990). This is further leveraged due to technological complexity of new innovations (Hagedoorn and Duysters, 2002).

Ring and Van de Ven (1994) point out the importance of equity in addition to traditional efficiency as criteria for assessing cooperative networks. With equity they mean 'fair deal', which does not require that inputs or outcomes are always divided equally between the parties, but all parties receive benefits proportional to their investment (some call it experience of reasonableness, e.g. Kohtamäki et al., 2006). We find this principle of fairness to be a distinctive character of collaborative networks. The partners are allowed to question the fairness of the deal from their point of view and either continue in the network or if not satisfied, withdraw from collaboration or renegotiate the terms of the co-operation, including coordination.

\subsection{Learning in Business Networks}

A common understanding is that knowledge-related capabilities are of central concern in the formation of networks (Möller and Halinen, 1999). Traditionally firms have approached collaboration from an exploitation view; they seek additional knowledge from other companies operating in similar or the same domain. The aim is to find matching knowledge-related capabilities that can be transferred, incorporated and appropriated in the assimilating firm (Nielsen, 2002). In this view, it is crucial that there is some similarity between the co-operating firms, for instance similarity of goals, services, staff skills, and clients (Van de Ven, 1976), so that they can absorb the innovation within a reasonable timeframe (Cohen \& Levinthal, 1990). This timeframe can be further shortened by improving the absorptive capacity within a firm by accumulating capacity in particular areas (Cohen \& Levinthal, 1990). An alternative motivation to form a business network may be to explore an external problem or opportunity in the overlapping domains of organisations (Van de Ven, 1976). In such cases the need emerges out of awareness, for example, of changing need priorities, resource distribution channels, or power relationships in the environment (Batt and Purchase, 2004). This explorative view challenges the traditional exploitative view especially in knowledge intensive environments (Nielsen, 2002). Whereas the traditional exploitative view is concerned with increasing productivity through standardisation, systematic cost reduction, 
and incremental improvement of existing technologies, skills and capabilities, exploration, in turn, is about finding new opportunities for wealth creation through building new capabilities and innovation. Nielsen (2002) pictures explorative networks as networks where new knowledge can be created among the participants as a synergy (and not simply the sum). As these explorative networks are concerned with new, innovative matters, they are facing more complexity in their tasks and outcomes and many risky explorative networks may fail in achieving their objectives and break up after only a short trial period (see e.g. Sivadas \& Dwyer, 2000).

Vervest et al. (2005) emphasise that there are three knowledge sharing related features that distinguish learning business networks from other value chains: Awareness, adaptiveness and capabilities to learn. With awareness they mean that the involved parties share relevant information. Adaptiveness means capabilities to coordinate the actions of network's members toward the new desired end-state. And, third, the network should have capabilities to learn; to innovate before forced to innovate. Knowledge sharing and mutual learning within a network presents considerable challenges, and this is no more so than in a network comprised of businesses with different histories and competencies and conflicting goals. Therefore, It takes time for the parties to work together and also to be ready to adapt their own operations and practices as and when cooperation requires it. In practice, this involves learning on multiple levels: cooperation requires changes within the network, within the individual company, and within bilateral relationships between companies. (Heikkilä et al., 2005).

\subsection{Coordination in Business Networks}

We can easily agree that the more complex the overall task or the more parties are involved, the greater the problem of coordinating becomes (Thompson, 1967; Galbraith, 1977). Although we all have an intuitive sense of what coordination means, an explicit definition is hard to articulate (Malone \& Crowston, 1994). According to Thompson (1967) coordination "consists of protocols, tasks and decision mechanisms designed to achieve concerted actions between interdependent units". It has aspects in common with words management and harmonisation, because it includes acts of handling and direction and aims to formation of a consistent whole (Malone \& Crowston, 1994).

While in hierarchies the typical coordination mechanisms are authority, rules and procedural standards, and in markets it is price, within networks 
trust is claimed to be the generic coordination mechanisms (Adler, 2001; Powell, 1990; Lorenzoni and Baden-Fuller, 1995; Ring \& Van de Ven, 1994). Willingness to rely on trust in dealing with partners involves judgments on the reliability of both people and organisations, and such judgments are subjected to continuous updating in the course of the collaborative endeavour (Mayer et al., 1995; Ariño et al., 2001; Zolin et al., 2004; Jarvenpaa et al., 1998). Trust, often defined as "confidence in another's goodwill" (Ring \& Van de Ven, 1992) comes from three sources: calculative form of trust via a sober assessment of the costs and benefits, familiarity through repeated interaction, and values and norms that engender trustworthy behaviour. Grandori and Soda (1995) reviewed the literature on coordination mechanisms in network research and find that many of the basic mechanisms applied within hierarchy (Galbraith, 1977) were also adjusted to network settings, such as routines, rules and procedures; inter-firm authorities (e.g. clusters of local firms accepting the leadership of a central firm), personal surveillance, direction of subordinates by superiors, control over the purchasing volumes allocated to each of its suppliers, target costing as well as contracts and contractual sanctions (Kohtamäki \& Kautonen, 2008; Kulmala et al., 2002). On the other hand, also internal competition, co-opetition is sometimes applied within networks (Holland \& Lockett, 1997; Mitronen \& Möller, 2003; Nalebuff and Brandenburger, 1996; Ritala, and Huizingh, 2014; Ritala \& Tidström, 2014), for instance by using e-auctions and property rights (Grandori \& Soda, 1995). Frequency of bidding, number of competitors, supplier switching time and the supplier's position in comparison to competitors reflect the use of price mechanisms in network setting (Kohtamäki \& Kautonen, 2008).

The above list shows how several types of coordination mechanisms are applied in networks and the task of the network partners is to recognise, adopt and update the suitable ones for their situation. Ideally, we should find a balanced combination of coordination mechanisms, where the positive contribution of each mechanism is maximised, while their negative effects are minimised. Kohtamäki and Kautonen (2008) explain how each mechanism has a different role in maximising the performance of the relationship: the role of market mechanism is to force the partner to maintain continuous development in order to keep up with the competitors; the use of hierarchical mechanism aims to steer the partner's efforts to match the core company's requirements; and social mechanism facilitates information sharing and learning within the network allowing improved process development and, consequently, performance (Kohtamäki \& Kautonen, 2008). Still, the scientific literature is limited on this topic and Kohtamäki (2010) calls for theories emphasising 
shared relationship management and joint value co-creation, and suggests that managing the network relations and simultaneously developing trust could be done through a shared planning and development process.

\section{Longitudinal Action Research}

In order to find answers to our research question: "What is the role of cocreation process of business models in coordinating the emerging business networks?" we set out to analyse the co-creation process in two longitudinal action research studies of emerging business networks. Especially, we studied the three areas recognised in the previous literature review as essential aspects of networked business modelling - learning and knowledge sharing, agreement over roles, responsibilities and coordination; and assessment of feasibility and fairness of the deal.

Action research approach applied in this study builds on pragmatist philosophy (Baskerville, 1996; Baskerville and Myers, 2004). Action researchers aim to make purposeful use of previous research to question whether they are useful in practice in the sense of helping people to better cope with the world or to create better organisations. The investigator and the research object are interactively linked so that the findings are literally created as the investigation proceeds (Guba and Lincoln, 1994). Action research is among the more qualitative and interpretative approaches. The close involvement is good for in-depth access to issues and data. It enables participation in action, rather than merely accessing opinions as is in the case in an interviewonly study (Walsham, 2006). On the other hand, context-bound approach makes generalisations difficult. Despite this, action research is seen to respond the needs for relevance in management research (Baskerville, 1999). Here it is used in an attempt to understand and model the co-BM in business networks.

The empirical data comes from two longitudinal action research cases, both lasting three years. The unit of analysis is not a single firm, but business networks, consisting of several interdependent partners that collaboratively developed joint service offering. In both cases the research was carried out by a group of researchers and practitioners. Founding on the research plans, the research projects were funded jointly by the business companies and research funding agencies.

The goal in both cases was to study and co-create BMs within business networks. Since our research process was based on action research, problem identification initiated an iterative process where theory was matched with 
findings and insights from the real life. The BM issues were analysed using various BM theories and models, and their pros and cons were discussed within the consortium. At the same time the research team analysed the organisational changes required to realise the planned co-BM. We studied the process of joint learning and information sharing within the network, and also analysed the change processes needed within the network and inside the organisations if the joint network was to be acceptable.

\subsection{Data Collection}

The case analysis required a collection of a considerable amount of data through interviews, meetings, workshops, surveys and official company documents, internal records and press releases (Table 1). Multiple sources of data enabled cross checking of information through triangulation (Denzin and Lincoln, 1994). The primary source of our data comes from 57 face-toface semi-structured theme interviews with the management and the persons responsible and most knowledgeable about the aims and practices related to co-creation of BM within the network companies. We interviewed persons from all companies in the networks, i.e. from three companies in Case $\mathrm{M}$ and from four companies in case L. The interviews typically lasted 1.5 to 2 hours.

During the interviews several memos were made and afterwards a short report was written about essential topics that were discussed during the interview. The search for new interviews and other data sources stopped when the last interviewees could not provide any new insights (Glaser \& Strauss, 1967). Prior to the interviews, a case study protocol and an interview protocol were developed to guarantee research reliability (Yin, 2009). As suggested by Yin (2009), the protocol consisted of five sections: the purpose of the study, data collection, report outline, semi-structured questions and evaluation. All interviews were recorded and transcribed. The transcribed interviews were checked by the interviewed, at the same time same clarifying questions may

Table 1 Data sources

\begin{tabular}{lccc}
\hline & Case M & Case L & Total \\
\hline Interviews & 42 & 15 & 57 \\
Workshops & 10 & 3 & 13 \\
Meetings & 63 & 30 & 93 \\
Other & 3 & 8 & 11 \\
\hline Total & 118 & 56 & 174 \\
\hline
\end{tabular}


have been asked. The additional data includes memos and observations from workshops with participants from several partner companies facilitated by the researchers concerning differing topics related to the BM. More confidential issues were discussed in one-to-one meetings. Workshops and meetings were documented mainly in memos. We also acquired information on customers by visits and observations (Cases $\mathrm{M}$ and $\mathrm{L}$ ), and by service pilot and surveys (case L).

To ensure that no valuable information has eluded the interviewers' attention, we analysed the data in a systematic way, using the qualitative data analysis approach proposed by Miles and Huberman (1994). First a long-list of quotes was selected from the interview transcripts, explaining or indicating the roles of co-BM (Miles \& Huberman, 1994). Then, in an inductive way, all the quotes were reviewed, which led to more quotes and the identification of the topics from the differing viewpoints of the interviewed actors. In this phase, the authors attempted to scrutinise the data, to reveal the discrepancies and the underlying causes. Finally, the author identified patterns (Miles \& Huberman 1994, p. 69) describing how the three roles are appearing within the empirical cases. The corrections made during the process increased the internal validity and also the usefulness of the results in the problem situation of the study (Iversen, 2007).

By examining two different industries we attempted to avoid industry sector specificity and ensure better transferability of the results. It should be noted that, besides differing industry sectors, the cases differed in the types of customers and customisation of the products delivered. Case M's services were larger in monetary value and highly customised to fit B-to-B customers processes. On the other hand, the services by Case L were standardised and aimed at two types of users simultaneously, the B-to-B customers and individual employees.

\subsection{Cases}

The Case $\mathrm{M}$ is about a network of three large firms that were co-creating a $\mathrm{BM}$ for providing joint after sales services for international industrial customers. In Case L four independent firms in health \& wellbeing sector were co-designing BM for business and private customers (Table 2).

The Case $\mathrm{M}$ focused on operation and maintenance services for global clients. The possibilities for this service emerged along with the advances in ICT, remote diagnostics, control and coordination systems; as well as the constant pressure to cut costs. The service required a lot of synchronisation 
Table 2 Two business networks

\begin{tabular}{lll}
\hline & Case M & Case L \\
\hline Industry sector & Industrial & Health \& Wellbeing \\
$\begin{array}{l}\text { Customers } \\
\text { Value proposition }\end{array}$ & B-to-B & B-to-B \\
& $\begin{array}{l}\text { Novel after-market } \\
\text { maintenance, repair } \\
\text { and operations services } \\
\text { supported by ICT }\end{array}$ & $\begin{array}{l}\text { Novel wellbeing services } \\
\text { for patients and occupa- } \\
\text { tional healthcare } \\
\text { customers }\end{array}$ \\
& 3 & \\
$\begin{array}{l}\text { No of business network } \\
\text { companies }\end{array}$ & & 4 \\
\hline
\end{tabular}

with clients, partners, and even to competitors information systems, in order to meet the needs of profitable, high-quality service offerings. The service focused on preventing breakdowns of customers' production machinery by combining remote diagnostics and localised services. The value proposition for the customers was efficient and predictable operation of their production machinery. The collaborative business model provided also new value potential to all partners (Table 3).

The Case L was a pharmaceutical case, in which four partners collaboratively developed services that would increase and improve the physical activity of their customers. The service focused on preventing health issues (such as obesity, type 2 diabetes) that are typical of Western industrialised countries. The core process of the service was designed as follows: A medical doctor in the Health Care Company prescribes the patient physical exercise instead

Table 3 Case $M$ value potential

\begin{tabular}{|c|c|}
\hline Stakeholder & Value Potential \\
\hline $\begin{array}{l}\text { Customer: the producer } \\
\text { of consumer products }\end{array}$ & $\begin{array}{l}\text { The production machinery is efficient and reliable. There are } \\
\text { less breakdowns that are extremely costly. }\end{array}$ \\
\hline Machinery provider & $\begin{array}{l}\text { Remote after sales services would provide steady and } \\
\text { continuous income. Also it would improve customer } \\
\text { relationship management and provide possibilities } \\
\text { for additional sales worldwide. }\end{array}$ \\
\hline $\begin{array}{l}\text { Enterprise software } \\
\text { and services provider }\end{array}$ & $\begin{array}{l}\text { By improving and combining the software in customers' } \\
\text { and machinery provider's sites, new types of B-to-B } \\
\text { ICT services can be offered. }\end{array}$ \\
\hline $\begin{array}{l}\text { Telecommunication } \\
\text { services provider }\end{array}$ & $\begin{array}{l}\text { A secure telecommunication channel is provided as an } \\
\text { elemental part of the service. The collaborative business } \\
\text { would provide also possibilities for new markets. }\end{array}$ \\
\hline
\end{tabular}


of or in addition to normal drugs. The changes in the physical wellbeing of the patient (e.g. body age index, body mass index, body fat percentage) are measured regularly at a pharmacy, and the patient is encouraged to increase his or her physical activity level. The data from each measurement session is stored to a cloud service provided by the consultancy company, and from this database it can deliver to the customers and other network partners aggregated reports on the changes in the physical wellbeing of the patient or a group of patients (for instance employees of a certain company or industry). This data is available when the patient is seeing her/his doctor again. The customers in question are employees from companies that in turn are customers of the occupational healthcare service provider. The networked BM creates value for all stakeholders involved as shown in Table 4.

Table 4 Case $M$ value potential

\begin{tabular}{ll}
\hline Stakeholder & Value Potential \\
\hline Customer: the patient & $\begin{array}{l}\text { Medical doctors prescribe patient appropriate physical exer- } \\
\text { cises. The changes in physical well-being are measured regu- } \\
\text { larly at a pharmacy and the patient is also encouraged to increase } \\
\text { his or her physical activity level. The underlying presumption } \\
\text { is that getting a prescription from medical doctors will make } \\
\text { patients more committed to increase physical activities, which } \\
\text { will improve their physical and mental well being. }\end{array}$ \\
$\begin{array}{ll}\text { Customer: the employer } \\
\text { (company) }\end{array}$ & $\begin{array}{l}\text { Employing companies have occupational healthcare programs } \\
\text { for their employees. Improving the lifestyle of employees will } \\
\text { improve their performance and attendance at work, mental } \\
\text { stability, happiness, etc. }\end{array}$ \\
$\begin{array}{l}\text { Occupational } \\
\text { Tealthcare provider } \\
\text { (Medical Doctors) }\end{array}$ & $\begin{array}{l}\text { and extended prescriptions as part of occupational healthcare } \\
\text { program. }\end{array}$ \\
Pharmacy & $\begin{array}{l}\text { More customers will visit pharmacies, which is an opportunity } \\
\text { to offer a new range of products and services to the customers. }\end{array}$ \\
Consultancy Company & $\begin{array}{l}\text { Developer of prescription forms (to be used by medical doctors) } \\
\text { and a cloud service storing and providing reports. Re-education } \\
\text { and training to medical doctors and pharmacies. }\end{array}$ \\
Pharmaceutical & $\begin{array}{l}\text { Delivering new pharmaceutical products and services to phar- } \\
\text { macies. }\end{array}$ \\
\hline
\end{tabular}




\section{Findings on the Co-Creation Process of Business Models}

In the heart of the co-creation process in the empirical cases was the development of business model for the service that the network partners are offering. We identified similar steps in the analysis of BM in both cases: they started with business model ontology definition, continued with the creation of first BM sketches, and then modifying them according to the demand-side requirements and supply-side restrictions of the network. In the Case L the resulting BM was also pilot tested and changes to the BM were made accordingly.

In both case networks the business modelling started from ontology. Ontology is an explicit simplified conceptualisation of the objects, concepts, and other entities related to the BM. Examples of ontologies are Canvas (Osterwalder and Pigneur, 2010), STOF (Bouwman et al., 2008), CSOFT (Heikkilä et al., 2010) and VISOR (El Sawy and Pereira, 2013). They are intended for somewhat different settings, so effort was put to find a suitable method. Both cases showed how the current BM ontologies and tools, even though highly used in industry, are still in infancy in regarding their suitability to network context. For instance in Case $\mathrm{L}$ we had to draw a separate Canvas for each four partners and then one describing the network level BM.

After drawing the first BM blueprints, the networks realised they have to estimate demand-side limitations, such as case and customer specific limitations and restrictions, and analyse their effects on the feasible BM instances. In practice this meant that, if the markets are not homogenous, either the customer segment is reduced in size, or there will most probably be several different realised instances of the BM. In our both co-BM cases more detailed investigation showed that there are different customer groups that required its own $\mathrm{BM}$, or at least some modifications to the generic one. The Business Networks also noted that the actual user and the buyer are different, for example in Case L the buyers are companies acquiring occupational health care services, but the users are the employees and the medical experts. Often demand-side limitations also rise from the laws and regulations. An example is the regulations concerning privacy, which introduces many restrictions on storing and transfer of data on private persons. This is especially a great concern in health and wellbeing services (Case L). Furthermore, the laws, such as work licenses and employment contract acts, differ from country to country and they should always be checked (as in Case M). The same applies to taxation.

The networks considered also supply-side restrictions that may affect the possibilities to offer specific products or services as planned. For instance, 
if the network is lacking expertise needed for a specific product or service, it either has to rule this service out from its offering or it must rethink the composition of the network. As suggested above, in terms of offering and organisation of the network, this implies that various market segments or areas should be served partially by different networks. This is especially important in global service business (such as Case M).

Before any large investments for instance on training or on information systems, Case $\mathrm{L}$ decided to have a pilot test of a minimum viable product (Ries, 2011). In the pilot, the networked BM was tested by providing the service to a group of customers for free. During the pilot observations on the fluency of the service was observed and also the customers' opinions were collected with surveys. These kinds of Reality checks can be carried out for example with tentative proof-of-concepts, prototypes, SWOT analysis, pilots and benchmarking. The focus can be on desirability, technological feasibility, functional testing, or economic viability of the BM. The results should be critically analysed and feed back to the previous stages should occur accordingly (Heikkilä et al, 2005)

All the above work toward co-BMI was intertwined with continues cycles of learning, assessments of the fairness of the deal and discussions over the roles and liabilities of each partner.

\subsection{Knowledge Sharing and Mutual Understanding}

The learning and sense making process in both cases was long and somewhat challenging. Because organisations' histories, strategies, practices, hierarchies, cultures and infrastructure influence the willingness to co-operation, both of our case networks consisted of companies that already had some previous experiences of each other, or at least they were being recommended by some trusted third party. The beginning of the co-learning can be very slow and cautious - our experience was that when a new person joined the discussions the learning process was halted until the new person reached the level of others. One company in Case L called the activity of composing the network as "hearing phase" and mentioned that a joint research project can be of help to launch the process. For instance a multi party research project, which studies new technologies or scans changes in social behavior of customers can help to create potential new joint business ideas.

At start each company was presenting their own business slides using the vocabulary ("liturgy") of their own company. The partners were for instance 
using the same word, but having different connotations to it, or in even more often they were discussing about the same thing but using differing words. In this situation sharing of knowledge was not really possible. One partner in Case L commented: "I see that the meetings are still more formal than they should be, thinking about trust building and conduct, communication could be more open". Another partner required openness: "I long for straight talk; that all could say straight what they want and expect".

However, during the process the partners started to use the concepts from BMs and after founding this common vocabulary used the BM sketches as dynamic conscription devices, which helped them to share their ideas, opinions and concerns over the joint business, and to improve the plans.

Interestingly, the Case Networks did not want to include customers to the early creation work. In Case $\mathrm{M}$ the companies claimed that the needs of the particular customer involved might get too much attention and the resulting BM would then not serve the other potential customers of the network. Instead, they see that more proper timing of co-creation with customers is during pilot testing, as in Case L one partner pointed out "Now we need to investigate the users more seriously. We don't know how they will react on this concept."

The Case Networks acknowledged the uncertainty related to the endeavour, sarcastically put in words by one of Case M companies when we discussed the strategic aims of the business network initiative: "Here we can safely experience and learn - also from failures - together with our partners".

Our case networks utilised several learning methods: Workshops and brainstorming sessions with different set of participants; Critical issues raised by the participants were sometimes in Case $\mathrm{M}$ assigned as 'homework', i.e., sent to the individual parties for resolution; Case $\mathrm{M}$ also applied mini-scenarios to estimate the business potential via alternative future developments; In both cases role plays made an abstract ideas more concrete by exchanging roles between parties/customers and acting accordingly in a fictive performance; Benchmarks or analogies (e.g. from related industries) helped to make the business model more understandable and concrete.

Naturally, the network partners can change as the co-creation process continues. During the process both case networks realised that there are some capabilities missing from the network, which means that they may need to search for additional partners. Similarly some partners can leave the network. This kind of change inevitable means restart of learning, of agreement over roles and of feasibility assessments. 


\subsection{Agreement Over Roles and Responsibilities}

In order for the network business model to be adapted to the activities of the member companies in practice, it is to be adjusted at the detailed level. In our cases the members first looked at the kinds of processes they already had and how the network could, by combining these processes, produce the desired outcome.

"The roles within the network should be specified. So for example, if you give patients the prescriptions and send them to pharmacy, then they will do some measurements, but we also want to do the measurements! Who decides what these measurements should be?"

Later on some process designs were suggested to be jointly drafted towards common process definitions. These defined the roles and investments required by the joint BM. Also the responsibilities and contractual liabilities were hot topic:

"... In short it should become clear where our jurisdiction ends and where the others start in order to plan the needed future activities"

An important aspect was to ensure data compatibility between the information systems of the partners.

"Of course connection or integration of partners' internal information systems and CRM [Customer Relationship Management] systems with the external cloud service is complex or challenging, but with a good planning together we can deal with it...."

Furthermore, our empirical cases evidenced that internal change management within a participating company is essential, if a partner hopes to gain approval for the cooperation by its staff members. As the co-BM might form only part of partners' operations, it has to be harmonised with the processes applied for producing other products and services. Thus, the company representatives in our cases were engaged for considerable periods in negotiations and lobbying at different levels within their own organisations. The internal adaptation was regarded necessary in order for the network's operations to be able to be accepted by each company and to be adapted to the company's own processes.

The negotiations over the roles of each partner and the processes included discussions on the investments on information systems, ownership of the data, and also access to the customers. These kinds of exact decisions also set the boundaries where the partners are willing to rely on the word of the others and where they wanted to have clear rules. 


\subsection{Assessment of the Feasibility and Fairness}

Companies will not adopt the co-BM if its aims conflict with their own strategies. In our cases, the partners in several workshops and other crossboundary discussions assessed and interpreted the company strategies and sought a suitable common strategically adjusted goal for the network.

"... it is not clear which value propositions all these actors, individually and collectively, are focusing on now, and if these values will be different in future."

The function of the business modelling procedure was to help to clarify the differences of interpretations and clarify dependencies.

"... this is one of the most relevant questions that we still not clearly can define. This is basically the money flow, who will pay, and who will get?"

"A lot can be done with data but that is a risk at the same time. We need to find out what threats there are and how these threats might affect our business."

In our Cases the feasibility and fairness of the deal was estimated by somewhat differing methods. In case M the partners created scenarios of the potential future states of the service business they were co-creating. We also discussed first separately and then jointly about how the background, such as expertise and infrastructure, brought to the joint business should be valued and what would be the fair way to divide the profits. In Case L the partners collected data and experiences from a pilot testing of the service. The importance of equity in addition to traditional efficiency as criteria for assessing cooperative networks was evident.

"... we have all the Lego bricks, we can actually build the process, but are we all going to have our shares?

\section{Discussion}

As a scientific contribution, we continue the discussion on the roles of business modelling in business networks (Palo and Tähtinen, 2013) and on how joint value co-creation could aid in developing trust and coordinating the networked actions (Kohtamäki, 2010). Kohtamäki (2010) suggests that managing the network relations and simultaneously developing trust could be done through a shared planning and development process. Building on the previous literature and findings from two longitudinal action research cases we propose that the co-creation process of business models within business network partners has three roles: facilitation of learning and trust, assessment of feasibility and 


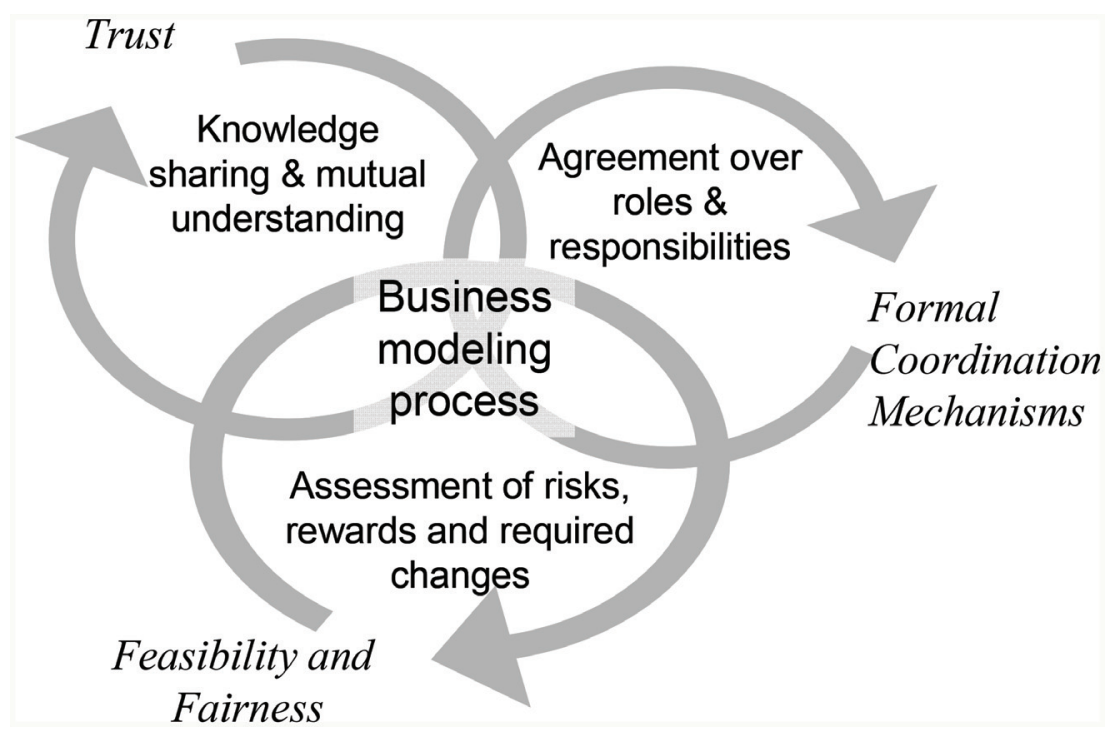

Figure 1 Triple role of co-creation process of BM in business networks.

fairness, and agreement on rules and responsibilities, which also determine the use of formal and structural coordination mechanisms. Our view resonates with the view that business modelling should be seen as a learning process (Baden-Fuller and Morgan, 2010; Robins, 2013; Itami and Nishino, 2010) and a co-creation process, where BM assumptions are both articulated and tested (McGrath, 2010), and which facilitates the management of collaboration between partners (Ritala et al., 2013). In Figure 1. we have summarised our understanding over the triple role of BM co-creation in Business Networks.

Our understanding is that the co-BM can aid the network in three ways:

\section{Co-creation of $B M$ increases trust through sharing of knowledge} and mutual learning. Business modelling helps to develop, capture, visualise, understand, communicate and share the business logic in coordinated manner (Osterwalder, 2004). In the co-creation process the BM acts as a dynamic boundary object (Star and Griesemer, 1989; Boland \& Tenkasi, 1995) helping the parties to understand each other's motives and goals, and to agree on joint goals for the cooperation. This alignment process is essential, since aligned values and norms signal trustworthy behaviour that leads to confidence (Adler, 2001). We see that the co-creation process supports the trust (or distrust) that comes from the familiarity through repeated interaction. 
2. Co-creation of BM facilitates assessment of feasibility and fairness of the deal. Since participation to a network is always voluntary, the potential partners should have some means to estimate the consequences of the cooperation. Concretely, business model co-creation process can improve measuring, observing and comparing the business logic. An explicit business model makes the evaluation of the fairness and risks associated with the deal possible and, thus, provides basis for the decision whether to join or not.

3. Co-creation of BM is a method to agree over roles and responsibilities and to settle the structural/formal coordination mechanisms. An important role of business modelling is to set rules for managing the collaboration (Osterwalder, 2004). BM provides means to analyse and agree on the roles and levels of partners. Practically, by the agreement on the business model the partners jointly settle the general coordination rules and procedures, for instance by committing themselves to investing in or using structural coordination mechanisms such as ICT systems. Even though the principal coordination mechanisms are trust-based, evidently they are combined with mechanism having hierarchical or market characteristics as well.

As Figure 1 shows the cycles are repeated and they are affecting each other. Thus, the suitable coordination mechanisms change during the process, and whenever the aspects of the business model are modified. Furthermore, the Figure 1 implies that the less the network has engaged in knowledge sharing and mutual understanding, the less trust, and the more formal coordination mechanisms are needed. An extreme example is a focal company, which designs the business model alone and without revealing the model assigns suppliers to carry out parts of the business. In these cases the role of trust in coordination can be practically non-existent.

Furthermore, the findings lead us to challenge the view of coordination familiar to us from the classic management theories and suggest that the main contribution of $\mathrm{BM}$ co-creation process is actually to function as a coordination framework. The classical management theories assume that managers can choose most effective coordination methods (Galbraith, 1974, 1977; Håkansson \& Snehota, 2006; Stacey, 2007; Kunz et al., 1998; Groth, 2001) and apply power within their hierarchical limits of authority in an ultimate aim to handle the exceptions challenging the stability of the organisation. However, the setting is fundamentally different in situations where the companies explore opportunities through collaboration in networks. 
In networks the interaction takes place between organisations that are pursuing their own goals and acting purposefully to explore new business prospects. The companies are consciously escalating the complexity by increasing the number of relationships and interdependencies and by aiming at more risky cooperation (Ramirez, 1999). The trade-off is between control and innovativeness; innovativeness does not thrive if the network is too tightly controlled by the focal company (Håkansson \& Ford, 2002). The main function of business network coordination is not to limit the complexity or to maintain stability. Instead the goal is to coordinate actions so that sharing of knowledge and learning within the network is advanced (Vervest et al., 2005).

The Figure 1. can thus be seen as an alternative managerial framework for thinking and conceptualising coordination in business networks: The cocreation process of $\mathrm{BM}$ where the $\mathrm{BM}$ acts as a dynamic boundary object (Doganova and Eyquem-Renault, 2009; Teece, 2010; Star and Griesemer, 1989; Gal et al., 2008) that facilitates communication between the network companies to co-design business collaboration, but also facilitates trust through knowledge sharing and guides the selection of coordination mechanisms. The aim of the business network coordination is to combine the capabilities and competences of several partners in a collaborative business effort. Therefore, the actual coordination mechanisms cannot and should not be decided by one party, but be agreed within the network (Ring \& Van de Ven, 1994) and the appropriateness (or success) is measured with the fairness of the deal to each of the parties (see also Table 5).

Table 5 Stylised view on business network coordination

\begin{tabular}{|c|c|c|}
\hline & $\begin{array}{l}\text { Classical Management Theory } \\
\text { View on Coordination (Galbraith, } \\
\text { 1974) }\end{array}$ & $\begin{array}{l}\text { Collaborative Network } \\
\text { View on Coordination }\end{array}$ \\
\hline \multirow[t]{2}{*}{ Context } & Within hierarchy & $\begin{array}{l}\text { Within Business } \\
\text { Networks }\end{array}$ \\
\hline & Cybernetic systems & Open systems \\
\hline Coordinator & Manager based on authority & Agreed in negotiations \\
\hline Mechanism & Hierarchical authority & $\begin{array}{l}\text { Co-creation process } \\
\text { of business models }\end{array}$ \\
\hline Aim & $\begin{array}{l}\text { Limit the complexity and } \\
\text { maintain stability }\end{array}$ & $\begin{array}{l}\text { To learn and combine } \\
\text { competences and } \\
\text { knowledge } \\
\text { (innovatively) }\end{array}$ \\
\hline Metrics for success & Efficiency of the organisation & $\begin{array}{l}\text { Efficiency and fairness } \\
\text { of the deal to each } \\
\text { partner }\end{array}$ \\
\hline
\end{tabular}


The practical implications concern the methods and means that the managers should apply to coordinate the activities. Drawing from our results, one of the most important managerial tasks would be to facilitate the process of designing, testing and evaluating the joint BMs. The emphasis should be on learning, knowledge sharing and mutual adjustments between the partners, but also on methods for assessing the fairness of the BM. More over, because inter-organisational learning especially in the beginning of the relationship is slow and cautious, it is important to have at least some permanent persons from each partner to ensure the knowledge transfer between the partners.

\section{Conclusions}

Drawing from two longitudinal cases of emerging business networks cocreating joint business models this study demonstrates how the BM was utilised as a dynamic boundary object in the co-creation process between the (potential) partners over the central aspects of the business networks' business collaboration. We suggest that business modelling can be of help when used as a framework by the network parties in creating trust and determining the suitable portfolio of coordination mechanisms for their business network. When the parties are engaged into negotiations over the aspects of joint business model, they are also engaging in a process of sense making and learning, where the trust is generated by direct interpersonal contacts, by understanding other parties' values and behaviour, and by calculations. In this co-creation process business model serves as a boundary object that facilitates communication between negotiating parties.

The main contribution of this article is synthesised into a proposition of triple role of co-creation process of business model. Firstly, it is essential in knowledge sharing, and mutual adjustment between the partners; and it facilitates generation of trust between the parties; Secondly, the risks, rewards and required changes are evaluated during the process. Thus, the partners are able to assess the feasibility and fairness of the deal and to decide whether to enter, stay or leave the network; and thirdly, it functions as a high level coordination framework, through which explicit agreement over roles and responsibilities can be operationalised into formal coordination mechanisms, such as joint rules and procedures, and contracts.

As a result of the BM co-creation process, the network consists of selected partners that find the collaboration as fair and feasible, and the coordination is based - at least to some extent - on trust, and is backed up with jointly agreed formal coordination mechanisms. That is, during the co-creation process the 
negotiating parties come to an understanding over the general framework of network coordination: how is the coordination responsibility shared between the parties, in which areas of the business model the network or part of the network can rely on hand shakes, and in which areas more formal contracts or use of market mechanism are needed. Last, the co-BM is valuable even if the partners did not in the end agree to collaborate, because it allowed the partners to make justified decision over the collaboration.

This study has its limitations. Firstly, the networked business model development is examined in the specific context of emerging business networks and the findings of the study can be applicable in other emerging business networks. However, the results may not be valid in established business networks. It is possible that when the business network is up and running, the role of business modelling will diminish, unless the business network is not aiming at new innovations. Another limitation relates to the collection of the empirical data. Even though both research projects continued for three years, the business networks were not ready to commercialise the joint business model yet. A follow up study would provide valuable information on where the co-creation processes of business models eventually led up to. Furthermore, additional studies on business modelling within business networks would provide more insight into the composition and coordination in different phases of collaboration.

\section{Acknowledgements}

The work leading to these results has received funding from the "Data to Intelligence (D2I)" Programme, and from the European Community's Horizon 2020 Programme (2014-2020) under grant agreement 645791. The content here in reflects only the authors' view. The European Commission is not responsible for any use that may be made of the information it contains.

\section{References}

[1] Adler, P. (2001). Market, Hierarchy, and Trust: The Knowledge: Economy and the Future of Capitalism. Organization Science, 12(2), 215-234.

[2] Afuah, A., and Tucci, C.(2003). Internet business models and strategies: text and cases. 2. ed. McGraw-Hill Higher Education.

[3] Andersen, P.H., and Christensen, P.R. (2000). Inter-partner learning in global supply chains: lessons from NOVO Nordisk. European Journal of Purchasing \& Supply Management. 6, 105-116. 
[4] Ariño, A., de la Torre, J., \& Ring, P. (2001). Relational Quality: Managing trust in corporate alliances. California Management Review, 44(1), 109-132.

[5] Baden-Fuller, C., and Morgan, M. (2010). Business models as models, Long Range Planning, 43, 156-171.

[6] Baraldi, E., Gregori, G. L., \& Perna, A. (2011). Network evolution and the embedding of complex technical solutions: The case of the Leaf House network. Industrial Marketing Management, 40(6), 838-852.

[7] Baregheh, A., Rowley, J., and Sambrook, S. (2009). Towards a multidisciplinary definition of innovation. Management Decision, 47, 1323-1339.

[8] Baskerville, R. (1996). Deferring generalizability: Four classes of generalization in social enquiry. Scandinavian Journal of Information System, 8(2), 5-28.

[9] Baskerville, R. (1999). Investigating Information Systems with Action Research. Communications of the Association for Information Systems, 2, Article 19, 1-32.

[10] Baskerville, R., \& Myers, M (2004). Special issue on action research in information systems: making IS research relevant to practice foreword. MIS Quarterly, 28(3), 329-335.

[11] Batt, P. J., \& Purchase, S. (2004). Managing collaboration within networks and relationships. Industrial Marketing Management, 33(3), 169-174.

[12] Berglund, H., and Sandström, C. (2013). Business Model Innovation from an Open Systems Perspective: Structural challenges and managerial solutions. International Journal of Product Development.

[13] Boland, R., \& Tenkasi, R. (1995). Perspective making and perspective taking in communities of knowing. Organization Science, 6(4), 350-372.

[14] Bouwman, H. (2003). Designing metrics for business models describing Mobile services delivered by networked organisations. In 16th Bled Electronic Commerce Conference eTransformation, 1-20.

[15] Bouwman, H., De Reuver, M., Solaimani, S., Daas, D., Haaker, T., Janssen, W., Iske, P., and Walenkamp, B. (2012). Business models, tooling and research agenda. In: 25th Bled eConference, Bled, Slovenia.

[16] Bouwman, H., De Vos, H., and Haaker, T. (2008). Mobile service innovation and business models. Springer.

[17] Busquets, J. (2010). Orchestrating smart business network dynamics for innovation. European Journal of Information Systems, 19, 481-493. 
[18] Casadesus-Masanell, R. and Ricart, J. E. (2011). How to design a winning business model. Harvard Business Review, 89, 100-107.

[19] Chesbrough, H. (2006). Open business models: How to thrive in the new innovation landscape. Harvard Business School Press.

[20] Chesbrough, H., and Rosenbloom, R. (2002). The role of the business model in capturing value from innovation: evidence from Xerox Corporation's technology spinoff companies. Industrial and Corporate Change, 11, 529-555.

[21] Chesbrough, H. (2010). Business model innovation: opportunities and barriers. Long Range Planning, 43, 354-363.

[22] Christopher, M. (1998). Relationships and Alliances. In J. Gattorna (Ed.). Strategic Supply Chain Alignment. England: Gower Publishing Ltd.

[23] Cohen, W., \& Levinthal, D. (1990). Absorptive Capacity: A New Perspective on Learning and Innovation. Administrative Science Quarterly, $35,128-152$.

[24] Denzin, N., \& Lincoln, Y. (1994). Introduction: Entering the field of qualitative research. In N. Denzin and Y. Lincoln (Eds.). Handbook of qualitative research. Sage Publications.

[25] Doganova, L., \& Eyquem-Renault, M. (2009). What do business models do?: Innovation devices in technology entrepreneurship. Research Policy, 38(10), 1559-1570.

[26] Dubosson-Torbay, M., Osterwalder, A., \& Pigneur, Y. (2002). E-business model design, classification, and measurements. Thunderbird International Business Review, 44(1), 5-23.

[27] EFactors (2003). E-business Model Roadmap. IST-2001-34868, European Commission IST Programme (2003)

[28] El Sawy, O., Pereira, F., 2013. Business Modelling in the dynamic Digital Space, Springer Briefs in Digital Spaces Springer, p. 68.

[29] Ford, D. and Håkansson, H. (2006), "The idea of business interaction", The IMP Journal, Vol. 1 No. 1, pp. 4-27.

[30] Frankenberger, K., Weiblen, T., Csik, M., and Gassmann, O. (2013a): The 4I-framework of business model innovation: an analysis of the process phases and challenges. International Journal of Product Development.

[31] Frankenberger, K., Weiblen, T., \& Gassmann, O. (2013b). Network configuration, customer centricity, and performance of open business models: A solution provider perspective. Industrial Marketing Management, 42(5), 671-682. 
[32] Gal, U., Lyytinen, K., \& Yoo, Y. (2008). The dynamics of IT boundary objects, information infrastructures, and organisational identities: the introduction of 3D modelling technologies into the architecture, engineering, and construction industry. European Journal of Information Systems, 17, 290-304.

[33] Galbraith, J. (1974). Organization Design: An Information Processing view. Interfaces, 4(3), 28-36.

[34] Galbraith, J. (1977). Organization Design. Reading, Massachusetts: Addison-Wesley.

[35] Glaser, B.G. and Strauss, A.L. (1967) The discovery of grounded theory: strategies for qualitative research, Aldine Transaction: A Division of Transaction Publishers, New Brunswick (USA) and London (UK).

[36] Grandori, A. (1997). An organizational assessment of interfirm coordination models. Organization Studies, 18, 897-925.

[37] Grandori, A., \& Soda, G. (1995), Inter-firm networks: Antecedents, Mechanisms and Forms. Organization Studies, 16(2), 183-214.

[38] Groth, L. (2001). Future Organizational Design: The Scope for the IT-based Enterprise, Wiley.

[39] Guba, E., and Lincoln, Y. (1994). Competing Paradigms in Qualitative Research. In: Denzin, N., Lincoln, Y. (Eds.) Handbook of qualitative research. Sage Publications (1994)

[40] Hagedoorn, J., \& Duysters, G. (2002). External Sources of Innovative Capabilities: The Preferences for Strategic Alliances or Mergers and Acquisitions. Journal of Management Studies, 39(2), 167-88.

[41] Heikkilä, M., Solaimani, S., Soudunsaari, A., Hakanen, M., Kuivaniemi, L., \& Suoranta, M. (2014). Performance Estimation of Networked Business Models: Case Study on a Finnish eHealth Service Project. Journal of Business Models, 2(1).

[42] Heikkilä, J., Heikkilä, M., \& Lehmonen, J. (2005). Sharing for understanding and doing for learning: An Emerging Learning Business Network. ICFAI Journal of Knowledge Management.

[43] Heikkilä, J., Heikkilä, M., and Tinnilä, M.(2008). The Role of Business Models in Developing Business Networks. in: Becker, A.S. (Ed.) Electronic Commerce: Concepts, methodologies, Tools, and Applications. Information Science Reference, 221-231. IGI Global.

[44] Heikkilä, M., and Kuivaniemi, L. (2012). Ecosystem Under Construction: An Action Research Study on Entrepreneurship in a Business Ecosystem. Technology Innovation Management Review, 18-24. 
[45] Heikkilä, J., Tyrväinen, P., and Heikkilä, M.(2010). Designing for performance $-\mathrm{a}$ technique for business model estimation. In: 10th EBRF Research Forum to Understand Business in Knowledge Society: Co-Creation as a Way Forward.

[46] Holland, C., \& Lockett, G. (1997). Mixed mode network structure: the strategic use of electronic communication by organizations. Organization Science, 8(5), 475-488.

[47] Håkansson, H., and Ford, D. (2002). How should companies interact in business networks?. Journal of Business Research, 55, 133-139.

[48] Håkansson, H., and Snehota, I. (1989, 2006). No business is an island: The network concept of business strategy, Scandinavian Journal of Management, 5(3), 187-200. Republished in 22(8), 256-270.

[49] Håkansson, H., and Snehota, I. (1995). Developing Relationships in Business Networks. Routledge, London IBM (2012). Global IBM CEO Study 2012. www-935.ibm.com/services/uk/en/c-suite/ceostudy2012/

[50] Itami, H., and Nishino, K., 2010. Killing two birds with one stone: profit for now and learning for the future. Long Range Planning, 43, 2, 364-369.

[51] Iversen, J. (2007). IS action research and its criteria. In N. Knock (Ed.), Information Systems Action research: An applied view of emerging concepts and methods (pp. 355-376). Springer.

[52] Jarvenpaa, S., Knoll, K., \& Leidner, D. (1998). Is Anybody Out There? Journal of Management Information Systems, 14(4), 29-64.

[53] Kautonen, T., \& Kohtamäki, M. (2006). Endogenous and Exogenous Determinants of trust in Inter-firm relations: conceptual analysis based on institutional economics, LTA, 3, 277-295.

[54] Kohtamäki, M. (2010). Relationship governance and learning in partnerships. Learning Organization, The, 17(1), 41-57.

[55] Kohtamäki, M., \& Kautonen, T. (2008). Conceptualising the dimensions of sourcing strategy: a governance-based approach. International Journal of Value Chain Management, 2(2), 206-226.

[56] Kohtamäki, M., Vesalainen, J., Varamäki, E., \& Vuorinen, T. (2006). The governance of partnerships and strategic network. Management Decision, 44(8), 1031-1051.

[57] Kulmala, H., Paranko, J., \& Uusi-Rauva, E. (2002). The role of cost management in network relationships. International Journal of Production Economics, 79, 33-43.

[58] Kunz, J., Christiansen, T., Cohen, G., Jin, Y., \& Levitt, R. (1998). The virtual design team. Communications of the ACM, 41(11), 84-91. 
[59] Lorenzoni, G., \& Baden-Fuller, C. (1995). Creating a Strategic Center to Manage a Web of Partners. California Management Review, 37(3), 146-163.

[60] Lusch, R. F., Vargo, S. L., \& Tanniru, M. (2010). Service, value networks and learning. Journal of the Academy of Marketing Science, 38(1), 19-31.

[61] Malone, T., \& Crowston, K. (1994). The Interdisciplinary Study of Coordination. ACM Computing Surveys, 26(1), 87-119.

[62] Mayer, R., Davis, J., \& Schoorman, D. (1995). An integration model of organizational trust. Academy of management review, 20(3), 709-734.

[63] McGrath, R. G., 2010. Business models: a discovery driven approach. Long range planning, 43, 2, 247-261.

[64] Miles, M.B., \& Huberman, A.M. (1994). Qualitative data analysis: An expanded sourcebook. Sage Publications, 2nd ed

[65] Mitronen, L., \& Möller, K. (2003). Management of Hybrid organizations: a case study in retailing. Industrial marketing management, 32, 419-429.

[66] Möller, K. K., \& Halinen, A. (1999). Business Relationships and Networks: Managerial Challenge of Network Era. Industrial marketing management, 28(5), 413-427.

[67] Möller, K., \& Svahn, S. (2009). How to influence the birth of new business fields - Network perspective. Industrial Marketing Management, $38,450-458$.

[68] Nalebuff, B., \& Brandenburger, A. (1996). Co-opetition. Profile Books.

[69] Nielsen, B. (2002). Synergies in Strategic Alliances: Motivation and Outcomes of Complementary and Synergistic Knowledge Networks. Journal of Knowledge Management Practices, 3.

[70] Osterwalder, A. (2004). The business model ontology: a proposition in a design science approach. Ph.D. Thesis, de l'Ecole des HEC de l'Université de Lausanne.

[71] Osterwalder, A., and Pigneur, Y. (2010). Business model generation: a handbook for visionaries, game changers, and challengers. John Wiley \& Sons.

[72] Palo, T., \& Tähtinen, J. (2013). Networked business model development for emerging technology-based services. Industrial Marketing Management, 42(5), 773-782.

[73] Parolini, C. (1999). The Value Net: A Tool for Competitive Strategy. John Wiley \& Sons, Chichester. 
[74] Powell, W. W. (1990). Neither Market nor Hierarchy. Research in Organizational Behavior, 12, 295-336.

[75] Powell, W. W. (2000). The Capitalist Firm in the 21st Century: emerging Patterns. In: DiMaggio, P. (ed.) the Twenty-First-Century Firm: Changing Economic Organization in International Perspective. Princeton University Press.

[76] Ramírez, R. (1999). Value co-production: Intellectual origins and implications for practice and research. Strategic Management Journal, 20(1), 49-65.

[77] Ries, E. (2011), The Lean Startup: How Today's Entrepreneurs Use Continuous Innovation to Create Radically Successful Businesses, Crown Publishing: New York.

[78] Ring, P., and Van de Ven, A. (1994). Developmental processes of cooperative interorganizational relationships. Academy of management review, 90-118.

[79] Ring, P., \& van de Ven, A. (1992). Structuring cooperative relationships between organizations. Strategic Management Journal.13, 483-498.

[80] Ritala, P., Agouridas, V., Assimakopoulos, D., \& Gies, O. (2013). Value creation and capture mechanisms in innovation ecosystems: a comparative case study. International Journal of Technology Management, 63(3), 244-267.

[81] Ritala, P., \& Huizingh, E. (2014). Business and network models for innovation: strategic logic and the role of network position. International Journal of Technology Management, 66(2), 109-119.

[82] Ritala, P., \& Tidström, A. (2014). Untangling the value-creation and value-appropriation elements of coopetition strategy: A longitudinal analysis on the firm and relational levels. Scandinavian Journal of Management.

[83] Robins, J., (2013). Editorial, Long Range Planning, 46, 6, 417-418.

[84] Rosenfeld, S.A. (1995). Industrial Strength Strategies: Regional Business Clusters and Public Policy. Aspen Institute, Washington, DC.

[85] Sivadas, E., \& Dwyer, R. (2000). An Examination of Organizational Factors Influencing New Product Success in Internal and AllianceBased Processes. Journal of Marketing, 64, 31-49.

[86] Stacey, R. (2007). Strategic Management and Organisational Dynamics: The Challenge of Complexity ( $5^{\text {th }}$ ed.), Prentice Hall.

[87] Star, S. L, \& Griesemer, J. R. (1989). Institutional ecology, 'Translations' and Boundary Objects: Amateurs and Professionals in Berkeley's 
Museum of Verteberate Zoology, 1907-39. Social Studies of Science, 19, 387-420.

[88] Svahn, S. (2004). Managing in Different Types of Business Nets: Capability Perspective (Diss. thesis, Helsinki School of Economics and Business Administration). ActaUniversitatisoeconomicaeHelsingi ensis.

[89] Teece, D. (2010). Business models, business strategy and innovation. Long range planning, 43, 172-194.

[90] Thompson, J. D. (1967). Organizations in Action: Social Science Bases in Administrative Theory. McGraw-Hill, New York.

[91] Timmers, P. (1998). Business models for electronic markets. Electronic markets, $8,3-8$.

[92] Tsai, W., \& Ghoshal, S. (1998). Social Capital and Value Creation: The Role of Intrafirm Networks. Academy of Management Journal, 41(4), 464-476.

[93] Van de Ven, A. (1976). On the Nature, Formation, and Maintenance of Relations Among Organizations. Academy of Management Review, 1(4), 24-36.

[94] Venkatraman, N., \& Henderson, J.C. (1998). Real strategies for virtual organizing, Sloan management Review, 40(1), 33-8.

[95] Vervest, P., van Heck, E., Preiss, K., \& Pau, L.-F. (2005). Smart Business Networks. Springer.

[96] Walsham, G. (2006). Doing interpretive research. European Journal of information systems, 15, 320-33.

[97] Westerlund, M., \& Rajala, R. (2010). Learning and innovation in interorganizational network collaboration. Journal of Business \& Industrial Marketing, 25(6), 435-442.

[98] Williamson, O.E (1985). The Economic Institutions of Capitalism: Firms, Markets, Relational Contracting. The Free Press, New York.

[99] Yin, R.K. (2009) Case study research: design and methods, Sage Publications, Inc. 4th Ed. (Applied social research methods v.5)

[100] Zolin, R., Hinds, P., Fruchter, R., \& Levitt, R. (2004). Interpersonal trust in cross-functional geographically distributed work: A longitudinal study. Information and Organization, 14, 1-26.

[101] Zott, C., and Amit, R.(2010). Business model design: an activity system perspective. Long range planning, 43, 216-226. 


\section{Biography}

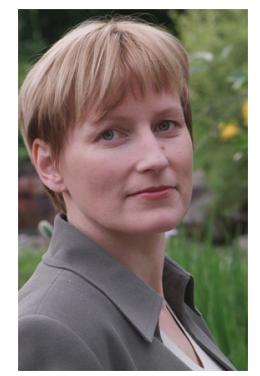

Marikka Heikkilä is a Senior Research Fellow at the University of Turku, Finland. She has an interest in information systems, business models and business model innovation, and collaboration and coordination in business networks, especially with regard to services. Currently, she works for a Horizon 2020 project (http://www.envisionproject.eu) aiming at activating small and medium-sized enterprises (SMEs) across Europe to re-think and transform their business models with the help of an easy-to-use, open-access web platform.

Marikka holds an MSc and a Licentiate of Science in Economics and Information Systems from the Helsinki School of Economics in Finland. She received her PhD from the Faculty of Information Technology at the University of Jyväskylä, Finland. She has authored numerous scientific articles, of which the most recent ones are appearing in the Journal of Theoretical and Applied Electronic Commerce Research (JTAER), Journal of Business Models (JOBM), TIM Review, and Technological Forecasting and Social Change. 